\title{
Grazing Management Impacts on Quail During Drought in the Northern Rio Grande Plain, Texas
}

\author{
LINDA CAMPBELL-KISSOCK, LYTLE H. BLANKENSHIP, AND LARRY D. WHITE
}

\begin{abstract}
Relationships between the abundance of 2 quail species and range site and grazing management during drought were evaluated in the northern Rio Grande Plain of Texas. Clay loam range sites provided better nesting cover and greater abundance of forbs for quail than sandy loam and shallow ridge range sites. Foliar cover and aboveground standing crop of grass were greater on the 3 range sites within the short duration and deferred rotation systems as compared with the yearlong system. During drought, grazing systems provided better nesting and protective cover for quail than yearlong grazing.
\end{abstract}

Recent grazing studies have shown that the primary values of grazing systems are increased forage production and range improvement (Heady 1961, Mathis et al. 1974, Kothmann 1975, Pieper et al. 1978). Many questions remain concerning effects of specialized grazing systems on wildlife populations.

Wildlife has always been a primary product of rangeland, and in recent years the economic value of game animals has become increasingly important to landowners in Texas. A growing interest in quail among Texas hunters points to the desirability of understanding effects of grazing management on quail populations. The objective of this study was to evaluate bobwhite (Colinus virginianus) and scaled (Callipepla squamata) quail indices of abundance in relation to vegetation parameters affected by grazing management and range site.

\section{Study Area}

The study was conducted from March through December 1980 on the Rio Grande Plain Experimental Ranch. The 4,228-ha ranch, located about $55 \mathrm{~km}$ west-southwest of Uvalde, Texas, is operated by the Texas Agricultural Experiment Station.

The area has a subtropical steppe climate characterized by mild winters and hot summers. The average annual rainfall is about 50 $\mathrm{cm}$, and periodic droughts are common. Over a 75 -year period, $53 \%$ of the annual rainfall has been below average with 1 of 4 years having less than $40 \mathrm{~cm}$ (Waldrip 1957). The frost-free period lasts about 285 days. Mean air temperatures range from $-4^{\circ} \mathrm{C}$ in January to $42^{\circ} \mathrm{C}$ in July.

Total rainfall for 1980 was $48 \mathrm{~cm}$, with major storms in May (18 $\mathrm{cm})$, August $(11 \mathrm{~cm})$ and November $(7 \mathrm{~cm})$, contributing $75 \%$ of the annual total. Only about $4 \mathrm{~cm}$ of precipitation fell during January through April, so spring vegetative growth and most quail breeding activity were delayed until after the May rainfall. Above average temperatures were recorded during June and July, with total rainfall during this period of only $2 \mathrm{~cm}$. Rainfall received in August

The authors were research assistant, wild life professor, and extension range specialist, Texas A\&M University Agricultural Research Center, Uvalde, Texas 78801. Campbell-Kissock currently is with the USDA Soil Conservation Service, Bryan, Texas.

The authors are grateful to Dr. Leon J. Folse, Jr., Department of Wildlife and Fisheries Sciences, Texas A\&M University, for his assistance with statistical and computer analyses. This report is published with approval of the Director, Texas Agricultural Experiment Station as TA 18155.

Manuscript accepted December 28, 1983. and November as a result of hurricanes relieved drought effects on vegetation.

The topography of the ranch is flat to gently sloping. Soils are clays (Entic Pellusterts), clay loams (Aridic Haplustolls, Aridic Calciustolls), sandy loams (Aridic Paleustalfs, Ustollic Calciorthids), and shallow gravelly loams (Petrocalcic Calciustolls, Ustollic Paleorthids). Located in the South Texas Plains Vegetational Area (Gould 1975), the ranch is typical of the mixed brush country of south Texas.

\section{Methods}

The grazing systems were initiated in 1975 and include a 6pasture, 1-herd short duration system, a 4-pasture, 3-herd deferred rotation system, and a 1-pasture, 1-herd yearlong system (Fig. 1). Pastures 9 and 11 of the short duration system, pasture 10 of the deferred rotation system, and pasture 12, grazed yearlong, comprised the study areas. These pastures were chosen because they included mixtures of the various range sites in somewhat equal proportions.

All grazing systems were stocked with Hereford $\times$ Brahman, Angus $\times$ Brahman, and Santa Gertrudis cows. The cattle under yearlong grazing were drylot fed from March 23-May 24 because of lack of forage and critical weight loss by animals due to drought.

The average 1980 yearlong stocking rates were $7.2,9.0$, and 9.4 ha/AU for the short duration, deferred rotation, and yearlong grazing systems, respectively. Actual stocking rates for each study pasture are shown in Figure 1. The short duration system was stocked $25 \%$ heavier than the other 2 systems. Of pastures used in the study, pasture 11 of the short duration system had the highest stocking rate during 1980 . Stocking densities (AU/ha during the grazing period) were greater for short duration pastures and least for the pasture grazed yearlong.

Clay loam, sandy loam, and shallow ridge range sites were sampled within each pasture in which they occurred. Thirty-four transects, each $150 \mathrm{~m}$ in length, were located randomly on each range site in each pasture. Ten, $0.25-\mathrm{m}^{2}$ plots, randomly located along each transect, were used to sample herbaceous vegetation in March, May, August, and December. Foliar cover was estimated for grass species using a gridded sampling frame with adjustable legs. A measure of forb abundance was determined by recording the number of $10-\mathrm{cm}^{2}$ grid areas, within the $0.25 \mathrm{~m}^{2}$ frame, in which each forb species occurred. Current standing crop of grasses and forbs was clipped at ground level for each plot and weighed in the field during each sampling period. Samples of clipped vegctation were oven dried to determine moisture content and dry weight of field samples.

Three methods were used to index quail abundance. Visual counts from horseback were made from May through December. Two permanent transects, each about $1.6 \mathrm{~km}$ long, were established in each of pastures 9,10 , and 11 , and 4 transects were placed in pasture 12. Transects were located across the 3 range sites in each pasture as equally as possible (Table 1). The transects were ridden monthly during morning and afternoon. Quail sightings were 

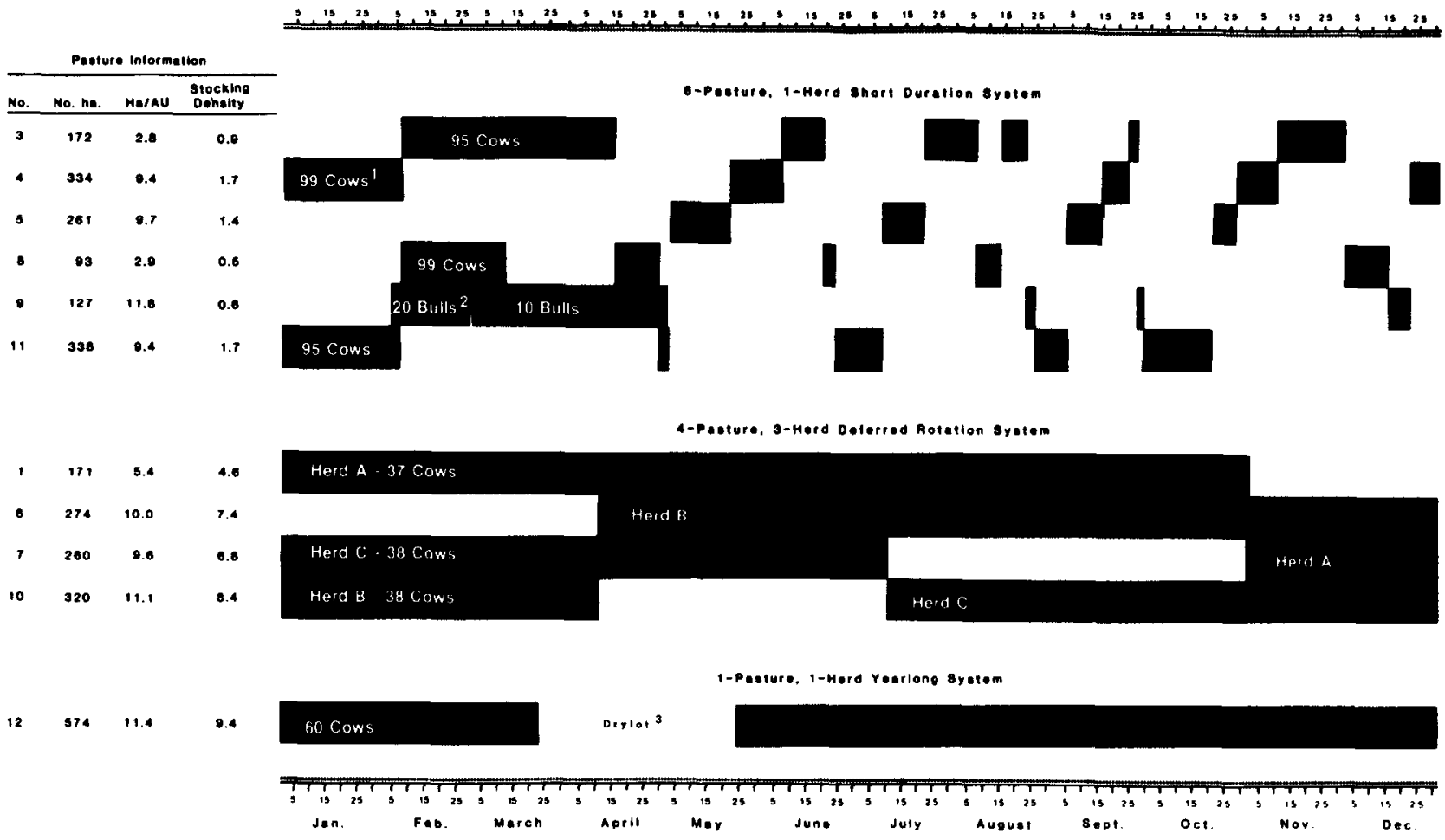

recorded by species, site, and pasture. Whistling cocks heard along horseback transects from May through July also were recorded.

Roadside whistle counts were conducted on 2 consecutive days every 2 weeks from May through July. Quail seen along the road during whistle counts were recorded as well. Visual roadside counts were made during the morning and afternoon of 2 consecutive days every 2 weeks from August through December. Both whistle and visual counts were made along a $16.1 \mathrm{~km}$ route through the study area. In addition, birds have been counted monthly from a vehicle along a $32 \mathrm{~km}$ route since 1976 (Table 2 ).

Indices of quail abundance were developed using the number of birds recorded for each method. These indices were used in correlation analysis with vegetation parameters. The indices are expressed as follows:

Table 1. Transect length (horseback) located in each site and pasture.
Horseback

Index:

$\frac{\text { Total no. of birds observed }}{\text { Total distance covered }(\mathrm{km})} \rightarrow \frac{\Sigma \text { of no counts }}{\mathrm{n} \times \text { transect length }}$

Whistle Index: $\frac{\text { Total no of birds heard }}{\text { Total no. of stops }} \rightarrow \frac{\Sigma \text { of no counts }}{n \times 10 \text { stops } / \text { count }}$

Roadside Index: Total no. of birds observed

Total distance covered $(\mathrm{km})$

$\Sigma$ of $\mathbf{n}$ (roadside + whistle) counts

$\mathrm{n} \times$ total distance covered along route

during roadside and whistle counts

The Chi-Square Goodness-of-fit test was used to determine if quail were observed more frequently than expected in each pasture and range site. To determine which cell of the Chi-Square test was contributing to significance a set of simultaneous confidence intervals was established (Neu et al. 1974) with Bonferroni $t$-statistic

\begin{tabular}{|c|c|c|c|c|c|}
\hline $\begin{array}{c}\text { Pasture and } \\
\text { grazing system ' }\end{array}$ & $\mathbf{H a}$ & Range site & $\mathrm{Ha}$ & $\begin{array}{l}\text { Distance in each } \\
\text { site }(\mathrm{km})\end{array}$ & $\begin{array}{c}\text { Total } \\
\text { distance }(\mathrm{km})\end{array}$ \\
\hline $9(\mathrm{SD})$ & 127 & $\begin{array}{l}\text { Clay loam } \\
\text { Shallow ridge }\end{array}$ & $\begin{array}{l}42 \\
77\end{array}$ & $\begin{array}{l}1.51 \\
1.68\end{array}$ & 3.19 \\
\hline 10 (DR) & 320 & $\begin{array}{l}\text { Clay loam } \\
\text { Sandy loam } \\
\text { Shallow ridge }\end{array}$ & $\begin{array}{r}157 \\
96 \\
67\end{array}$ & $\begin{array}{l}1.06 \\
1.43 \\
0.73\end{array}$ & 3.22 \\
\hline 11 (SD) & 338 & $\begin{array}{l}\text { Clay loam } \\
\text { Sandy loam } \\
\text { Shallow ridge }\end{array}$ & $\begin{array}{r}223 \\
112 \\
3\end{array}$ & $\begin{array}{l}1.61 \\
1.38 \\
0.26\end{array}$ & 3.25 \\
\hline $12(Y)$ & 574 & $\begin{array}{l}\text { Clay loam } \\
\text { Sandy loam } \\
\text { Shallow ridge }\end{array}$ & $\begin{array}{r}333 \\
201 \\
40\end{array}$ & $\begin{array}{l}2.72 \\
2.99 \\
0.82\end{array}$ & 6.53 \\
\hline
\end{tabular}

'SD-Short Duration, DR-Deferred Rotation, Y-Yearlong. 
Table 2. Average number of quail $/ 32 \mathrm{~km}$ seen on monthly counts from a vehicle on the Rio Grande Plain Experimental Ranch from 1976 through 1980.

\begin{tabular}{lcc}
\hline Year & $\begin{array}{c}\text { Bobwhite } \\
\text { Quail }\end{array}$ & $\begin{array}{c}\text { Scaled } \\
\text { Quail }\end{array}$ \\
\hline 1976 & 18 & 4 \\
1977 & 52 & 9 \\
1978 & 15 & 2 \\
1979 & 19 & 5 \\
1980 & 3 & 1 \\
\hline
\end{tabular}

approximated (Miller 1981, p. 70).

\section{Results and Discussion}

Quail populations were low throughout the study period due to drought conditions beginning in 1979 and continuing through April 1980.

Foliar cover of grasses was significantly greater on clay loam sites compared to sandy loam and shallow ridge sites during each sampling period and over all sampling dates in each of the 4 pastures (Table 3). Clay loam sites in pastures 9 of the short duration system and 10 of the deferred rotation system had greater grass cover than the same range site in pasture 12 , grazed yearlong.

Aboveground standing crop of grass was significantly greater on clay loam sites compared to sandy loam and shallow ridge sites during each sampling period and over all dates in each of the pastures (Table 3). Short duration pasture 9 had greater grass weights on clay loam sites compared to other pastures. Trends showed that pasture 12, grazed yearlong, had the lowest grass weights on each of the 3 range sites. Pasture 9 had the lowest stocking rate at $11.8 \mathrm{ha} / \mathrm{AU}$ and short duration pasture 11 the highest at $9.4 \mathrm{ha} / \mathrm{AU}$.

Forb abundance was generally higher on clay loam sites, although there were few significant differences (Table 3). Forbs were most abundant on clay loam sites in pasture 12 of the yearlong system.

Although Chi-Square analysis showed that bobwhite use of at least one of the pastures was significantly different than expected $(\propto<.025)$, use of Bonferroni $t$-statistic showed that quail occurred in each pasture with expected frequency (Table 4). Scaled quail

Table 3. Differences in grass cover, weights and forb abundance for range sites by dates and pastures.

\begin{tabular}{|c|c|c|c|c|c|c|c|c|c|}
\hline \multirow[b]{2}{*}{$\begin{array}{l}\text { Range } \\
\text { site }\end{array}$} & \multicolumn{4}{|c|}{ Date $^{1}$} & \multicolumn{5}{|c|}{ Pasture ${ }^{2}$} \\
\hline & March & May & Aug. & Dec. & $\begin{array}{r}9 \\
\mathrm{SD}\end{array}$ & $\begin{array}{c}10 \\
\text { DR }\end{array}$ & $\begin{array}{c}11 \\
\text { SD }\end{array}$ & $\begin{array}{r}12 \\
Y\end{array}$ & Avg. \\
\hline & \multicolumn{9}{|c|}{ Grass cover $\left(\mathrm{m}^{2} / \mathrm{ha}\right) \times 10^{-2}$} \\
\hline $\begin{array}{l}\text { Clay loam } \\
\text { Sandy loam } \\
\text { Shallow ridge }\end{array}$ & $\begin{array}{l}2.6^{\mathrm{a}} \\
1.0^{\mathrm{b}} \\
0.7^{\mathrm{b}}\end{array}$ & $\begin{array}{l}3.5^{\mathrm{a}} \\
1.0^{\mathrm{b}} \\
0.7^{\mathrm{b}}\end{array}$ & $\begin{array}{l}4.4^{\mathrm{a}} \\
1.3^{\mathrm{b}} \\
1.0^{\mathrm{b}}\end{array}$ & $\begin{array}{l}3.4^{\mathrm{a}} \\
1.1^{\mathrm{b}} \\
0.7^{\mathrm{b}}\end{array}$ & $\frac{3.9^{\mathrm{a}}}{1.2^{\mathrm{c}}}$ & $\begin{array}{l}4.2^{\mathrm{a}} \\
1.1^{\mathrm{c}} \\
0.8^{\mathrm{c}}\end{array}$ & $\begin{array}{l}3.3^{\mathrm{ab}} \\
1.4^{\mathrm{c}} \\
0.7^{\mathrm{c}}\end{array}$ & $\begin{array}{l}2.7^{b} \\
0.7^{c} \\
0.4^{c}\end{array}$ & $\begin{array}{l}3.5^{\mathrm{a}} \\
1.1^{\mathrm{b}} \\
0.8^{\mathrm{b}}\end{array}$ \\
\hline Shallow ridge & \multicolumn{9}{|c|}{ Grass weights $\left(\mathrm{g} / \mathrm{m}^{2}\right)$} \\
\hline $\begin{array}{l}\text { Clay loam } \\
\text { Sandy loam } \\
\text { Shallow ridge }\end{array}$ & $\begin{array}{r}24.0^{\mathrm{a}} \\
9.3^{\mathrm{b}} \\
8.7^{\mathrm{b}}\end{array}$ & $\begin{array}{r}39.2^{\mathrm{a}} \\
10.2^{\mathrm{b}} \\
4.9^{\mathrm{b}}\end{array}$ & $\begin{array}{r}77.2^{\mathrm{a}} \\
19.0^{\mathrm{b}} \\
9.7^{\mathrm{b}}\end{array}$ & $\begin{array}{r}50.1^{\mathrm{a}} \\
14.0^{\mathrm{b}} \\
8.1^{\mathrm{b}}\end{array}$ & $\begin{array}{c}72.6^{\mathrm{a}} \\
\overline{10.1^{\mathrm{c}}}\end{array}$ & $\begin{array}{r}45.7^{\mathrm{b}} \\
15.7^{\mathrm{c}} \\
8.0^{\mathrm{c}}\end{array}$ & $\begin{array}{r}41.8^{b} \\
13.2^{c} \\
7.3^{c}\end{array}$ & $\begin{array}{r}32.7^{b} \\
10.1^{c} \\
5.3^{c}\end{array}$ & $\begin{array}{r}48.2^{\mathrm{a}} \\
13.0^{\mathrm{b}} \\
7.7^{\mathrm{b}}\end{array}$ \\
\hline Shallow ridge & \multicolumn{9}{|c|}{ Forb Abundance ${ }^{3}$} \\
\hline $\begin{array}{l}\text { Clay loam } \\
\text { Sandy loam } \\
\text { Shallow ridge }\end{array}$ & $\begin{array}{l}6.5^{\mathrm{a}} \\
3.7^{\mathrm{a}} \\
5.6^{\mathrm{a}}\end{array}$ & $\begin{array}{r}10.2^{\mathrm{a}} \\
8.6^{\mathrm{a}} \\
7.3^{\mathrm{a}}\end{array}$ & $\begin{array}{r}12.5^{\mathrm{a}} \\
9.6^{\mathrm{b}} \\
7.7^{\mathrm{b}}\end{array}$ & $\begin{array}{l}27.7^{a} \\
22.9^{b} \\
20.6^{b}\end{array}$ & $\begin{array}{c}10.2^{\mathrm{bcd}} \\
\overline{-}^{\mathrm{cod}}\end{array}$ & $\begin{array}{c}15.7^{\mathrm{ab}} \\
11.0^{\mathrm{bcd}} \\
9.9^{\mathrm{cd}}\end{array}$ & $\begin{array}{c}14.8^{\text {abc }} \\
8.6^{\text {d }} \\
11.2^{\text {abcd }}\end{array}$ & $\begin{array}{l}16.7^{\mathrm{a}} \\
13.3^{\mathrm{abcd}} \\
10.7^{\mathrm{bcd}}\end{array}$ & $\begin{array}{l}14.3^{\mathrm{a}} \\
11.0^{\mathrm{a}} \\
10.3^{\mathrm{a}}\end{array}$ \\
\hline
\end{tabular}

Data are compared by column. Means followed by the same letter do not differ significantly at the $5 \%$ level by Duncan's new multiple range test.

2Means followed by the same letter do not differ significantly at the $5 \%$ level by Duncan's new multiple range test. SD-Short Duration, DR-Deferred Rotation, Y-Yearlong.

${ }^{3}$ Average number of $10 \mathrm{~cm}^{2}$ grid areas in which forb species occurred (based on $10,0.25 \mathrm{~m}^{2}$ plots $/$ transect or 250 grid areas).

Table 4. Occurrence of quail in each pasture on the 1359 ha study area from May through December 1980.

\begin{tabular}{|c|c|c|c|c|c|c|}
\hline Species & $\begin{array}{l}\text { Pasture } \\
\text { and } \\
\text { grazing } \\
\text { system }\end{array}$ & $\begin{array}{l}\text { Proportion of } \\
\text { total transect } \\
\text { length } \\
\left(\mathrm{Pi}_{\mathrm{o}}\right)\end{array}$ & $\begin{array}{c}\text { Number of } \\
\text { quail } \\
\text { observed }\end{array}$ & $\begin{array}{c}\text { Expected number } \\
\text { of quail } \\
\text { observed }\end{array}$ & $\begin{array}{c}\text { Proportion } \\
\text { observed } \\
\text { in } \\
\text { each pasture } \\
\text { (Pi) }\end{array}$ & $\begin{array}{c}\text { Confidence interval on } \\
\text { proportion of } \\
\text { occurrence ( } 95 \% \\
\text { family confidence } \\
\text { coefficient) }\end{array}$ \\
\hline Bobwhite & $\begin{array}{l}9(\mathrm{SD}) \\
10(\mathrm{DR}) \\
11(\mathrm{SD}) \\
12(\mathrm{Y})\end{array}$ & $\begin{array}{l}.197 \\
.199 \\
.201 \\
.403\end{array}$ & $\begin{array}{l}14 \\
29 \\
17 \\
59\end{array}$ & $\begin{array}{l}23 \\
24 \\
24 \\
48\end{array}$ & $\begin{array}{l}.118 \\
.244 \\
.143 \\
.496\end{array}$ & $\begin{array}{r}0 \leq \mathrm{P}_{1} \leq .236 \\
.086 \leq \mathrm{P}_{2} \leq .402 \\
.014 \leq \mathrm{P}_{3} \leq .272 \\
.312 \leq \mathrm{P}_{4} \leq .680\end{array}$ \\
\hline Total & & 1.00 & 119 & 119 & & \\
\hline Scaled & $\begin{array}{r}9 \\
10 \\
11 \\
12\end{array}$ & $\begin{array}{l}.197 \\
.199 \\
.201 \\
.403\end{array}$ & $\begin{array}{r}33 \\
8 \\
4 \\
8\end{array}$ & $\begin{array}{l}10 \\
11 \\
11 \\
21\end{array}$ & $\begin{array}{l}.623 \\
.151 \\
.075 \\
.151\end{array}$ & $\begin{array}{r}356 \leq \mathrm{P}_{1} \leq 890 \\
0 \leq \mathrm{P}_{2} \leq .348 \\
0 \leq \mathrm{P}_{3} \leq .220 \\
0 \leq \mathrm{P}_{4} \leq .348\end{array}$ \\
\hline Total & & 1.00 & 53 & 53 & & \\
\hline
\end{tabular}

Proportions of total transect length represent expected quail observation values as if quail occurred in each pasture in exact proportion to availability.

${ }^{b}$ Calculated by multiplying proportion $\mathrm{Pi}_{\mathrm{o}} \times \mathrm{n}$; i.e., $.430 \times 119=48$.

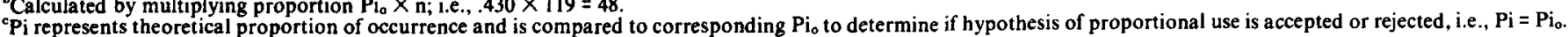




\begin{tabular}{|c|c|c|c|c|c|c|}
\hline Species & $\begin{array}{l}\text { Range } \\
\text { site }\end{array}$ & $\begin{array}{l}\text { Proportion of } \\
\text { total transect } \\
\text { length } \\
\left(\mathrm{Pi}_{\mathrm{o}}\right)\end{array}$ & $\begin{array}{c}\text { Number of } \\
\text { quail } \\
\text { observed }\end{array}$ & $\begin{array}{c}\text { Expected number } \\
\text { of quail } \\
\text { observed }\end{array}$ & $\begin{array}{l}\text { Proportion } \\
\text { observed } \\
\text { in each } \\
\text { range site } \\
\text { (Pi) }\end{array}$ & $\begin{array}{c}\text { Confidence interval on } \\
\text { proportion of } \\
\text { occurrence ( } 95 \% \\
\text { family confidence } \\
\text { coefficient) }\end{array}$ \\
\hline Bobwhite & $\begin{array}{l}\text { Clay loam } \\
\text { Sandy loam } \\
\text { Shallow ridge }\end{array}$ & $\begin{array}{l}.426 \\
.358 \\
.216\end{array}$ & $\begin{array}{r}96 \\
14 \\
9\end{array}$ & $\begin{array}{l}51 \\
42 \\
26\end{array}$ & $\begin{array}{l}.807 \\
.118 \\
.076\end{array}$ & $\begin{array}{r}.646 \leq P_{1} \leq .968 \\
0 \leq P_{2} \leq .250 \\
0 \leq P_{3} \leq .184\end{array}$ \\
\hline Total & & 1.00 & 119 & 119 & & \\
\hline Scaled & $\begin{array}{l}\text { Clay loam } \\
\text { Sandy loam } \\
\text { Shallow ridge }\end{array}$ & $\begin{array}{l}.426 \\
.358 \\
.216\end{array}$ & $\begin{array}{r}23 \\
2 \\
28\end{array}$ & $\begin{array}{l}23 \\
19 \\
11\end{array}$ & $\begin{array}{l}.434 \\
.038 \\
.528\end{array}$ & $\begin{array}{r}.130 \leq \mathrm{P}_{1} \leq .738 \\
0 \leq \mathrm{P}_{2} \leq 155 \\
.222 \leq \mathrm{P}_{3} \leq .834\end{array}$ \\
\hline Total & & 1.00 & 53 & 53 & & \\
\hline
\end{tabular}

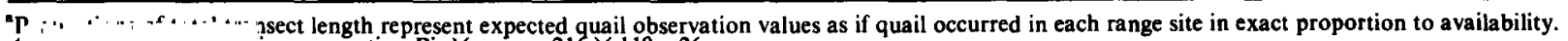

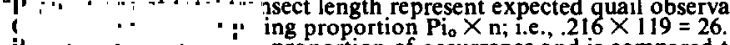

proportion of occurrence and is compared to corresponding $\mathrm{Pi}_{\text {o }}$ to determine if hypothesis of proportional use is accepted or rejected, $\mathrm{i}$.e., $\mathrm{P} i \mathrm{Pi}$.

were observed more frequently than expected in short duration pasture 9, i.e., expected use of pasture 9 was .197 while confidence intervals on observed use were $.356 \leq \mathrm{Pi}<.890$. Scaled quail use of pasture 12, grazed yearlong was less than expected. Pasture 9 consisted of $61 \%$ shallow ridge range site, whereas pasture 12 contained only $7 \%$ shallow ridge site.

Clay loam range sites were used significantly more frequently by bobwhite quail, while both sandy loam and shallow ridge sites were used less frequently than expected (Table 5). Scaled quail were observed on shallow ridge range sites signficantly more often than expected, whereas sandy loam sites were used less frequently. Scaled quail were observed on clay loam sites with expected frequency.

Whistle count data showed that $81 \%$ (155) of the bobwhite whistling cocks recorded in pastures 10,11 , and 12 from April through September were on clay loam sites. These sites provided the greatest perennial grass cover. Sandy loam and shallow ridge sites had $18 \%$ and $1 \%$ of the bobwhites, respectively. The importance of grass cover to nesting bobwhites has been reported by Lehmann (1946), Parmalee (1955), and Jackson (1972) in Texas. Scaled quail differed from bobwhite with 37,49 and $14 \%$ of the calls being recorded on clay loam, sandy loam, and shallow ridge sites, respectively. In west Texas, Wallmo (1956) observed that calling scaled quail males wandered extensively from one elevated perch to another. This behavior may be reflected in this study. Although scaled quail frequently were observed on shallow ridge sites, the lack of herbaceous cover on these sites probably prevented their use as nesting habitat.

A number of significant correlations were seen between bobwhite quail indices and vegetation parameters (Table 6). Both horseback and whistle indices showed significant positive relation- ships between cover and weight of grasses and bobwhite abundance. Correlation coefficients were highest for the whistle index as compared with the horseback index. There were significant positive relationships between bobwhite quail and forb abundance and weight in pastures 11 (short duration) and 12 (yearlong). Forb height was also significantly related to bobwhite abundance in pasture 12 (Table 6).

Few significant correlations were found between scaled quail indices of abundance and vegetation parameters. Perhaps scaled quail were less specific in their habitat preferences under the environmental conditions of this study, and were therefore less likely to show relationships.

\section{Conclusion}

The clay loam range site was most important in providing adequate nesting and screening cover and a greater abundance of forbs for quail during the drought year of 1980 . Bobwhite quail were particularly dependent upon this habitat type. The more moist clay loam sites may be analogous to bottomlands, identified by Jackson (1972) as "key" habitat for bobwhite quail in the Rolling Plains of Texas. Vegetation on both habitat types was more stable than on other sites during drought. The preference of bobwhite quail for greater herbaceous cover, provided by the clay loam site during the nesting season, was shown by whistle counts.

In southwestern Texas where periodic droughts are common, fluctuations in bobwhite populations are expected. Land managers interested in maintaining highest quail populations during drought years should consider quail habitat requirements when planning practices which affect clay loam range sites. The trend toward greater grass cover and weight within short-duration and deferred rotation pastures showed these grazing systems to be more valua-

Table 6. Correlation coefficients of bobwhite quail abundance indices and vegetation parameters.

\begin{tabular}{|c|c|c|c|c|c|c|c|c|}
\hline \multirow[b]{3}{*}{ Vegetation parameters } & \multicolumn{4}{|c|}{ Horseback index } & \multicolumn{4}{|c|}{ Whistle index } \\
\hline & \multicolumn{4}{|c|}{ Pastures } & \multicolumn{4}{|c|}{ Pastures } \\
\hline & 10 & 11 & 12 & Total & 10 & 11 & $12^{\circ}$ & Total \\
\hline $\begin{array}{l}\text { Grass cover } \\
\text { Grass weight }\end{array}$ & $0.84^{*}$ & & $0.78^{*}$ & $0.47^{* *}$ & $0.88^{*}$ & $0.96^{* *}$ & & \\
\hline Grass weight & $0.80^{*}$ & $0.74^{*}$ & $0.88^{* *}$ & & $0.89^{*}$ & $0.89^{*}$ & $0.87^{*}$ & \\
\hline Forb abundance & & $0.70^{*}$ & & & & & $0.87^{*}$ & $0.85^{* *}$ \\
\hline Forb weight & & & $0.89 * *$ & & & & $0.97 * *$ & $0.70^{* *}$ \\
\hline Forb height & & & $0.80^{* * *}$ & & & & $0.85^{*}$ & \\
\hline
\end{tabular}

*Significant at $P<0.05$ level.

**Significant at $P<0.01$ level.

Correlations that were not significant are not shown. 
ble than continuous grazing in providing adequate nesting and protective cover for bobwhites during a drought year. The higher abundance of forbs and lower cover and weight of grasses under yearlong grazing also indicated range deterioration compared to use of a rotational grazing system. Chamrad et al. (1982) showed 5 -year average beef production and net income per hectare highest for short duration grazing and lowest for yearlong grazing. Hence, better grazing management for cattle was also best for quail production under drought conditions.

\section{Literature Cited}

Campbell, H., D.K. Martin, P.E. Ferkovick, and B.K. Harris. 1973. Effects of hunting and some other environmental factors on scaled quail in Ncw Mexico. Wildl. Mongor. 34.

Chamrad, A.D., L.W. Varner, and P.O. Reardon. 1982. Efficiency and economics of grazing systems in the Rio Grande Plain. p. 155-157. In: Proc. A National Conference on Grazing Management Technology, Nov. 10-12, Texas A\&M Univ., College Sta.

Gould, F.W. 1975. Texas plants, a checklist and ecological summary. Texas A\&M Univ. Agr. Exp. Sta. Misc. Pub. 585 (Rev.).

Heady, H.F. 1961. Continuous vs. specialized grazing systems: a review and application to the California annual type. J. Range Manage. 14:182-193.
Jackson, A.S. 1972. Quail management handbook for west Texas Rolling Plains. Texas Parks and Wildl. Bull. 48.

Kothmann, M.M. 1975. Grazing management systems. Texas Agr. Prog. 21:22-23.

Lehmann, V.W. 1946. Bobwhite quail reproduction in southwestern Texas. J. Wildl. Manage. 10:111-123.

Mathis, G.W., M.M. Kothmann, and G.K. Burton. 1974. Cow-calf response to high-intensity, low-frequency grazing. Texas Agr. Sta. PR-3236.

Miller, R.G., Jr. 1981. Simultaneous statistical inference. 2nd Ed. SpringerVerlag, N.Y.

Neu, C.W., C.R. Byers, and J.M. Peek. 1974. A technique for analysis of utilization-availability data. J. Wildl. Manage. 38:541-545.

Parmalee, P.W. 1955. Some factors affecting nesting success of bobwhite quail in east central Texas. Amer. Midl. Natur. 53:45-55.

Pieper, R.D., G.B. Donart, E.E. Parker, and J.D. Wallace. 1978. Livestock and vegetational response to continuous and 4-pasture, I-herd grazing systems in New Mexico. First Int. Rangeland Cong. Proc., Denver, Colo.

Waldrip, W.J. 1957. Farming and ranching risk as influenced by rainfall. III. Rio Grande Plain of Texas. Texas Agr. Exp. Sta. MP 241, College Station.

Wallmo, 0.C. 1956. Ecology of scaled quail in west Texas. Texas Game and fish Comm. Spec. Rep., P-R Proj. W-57-R.

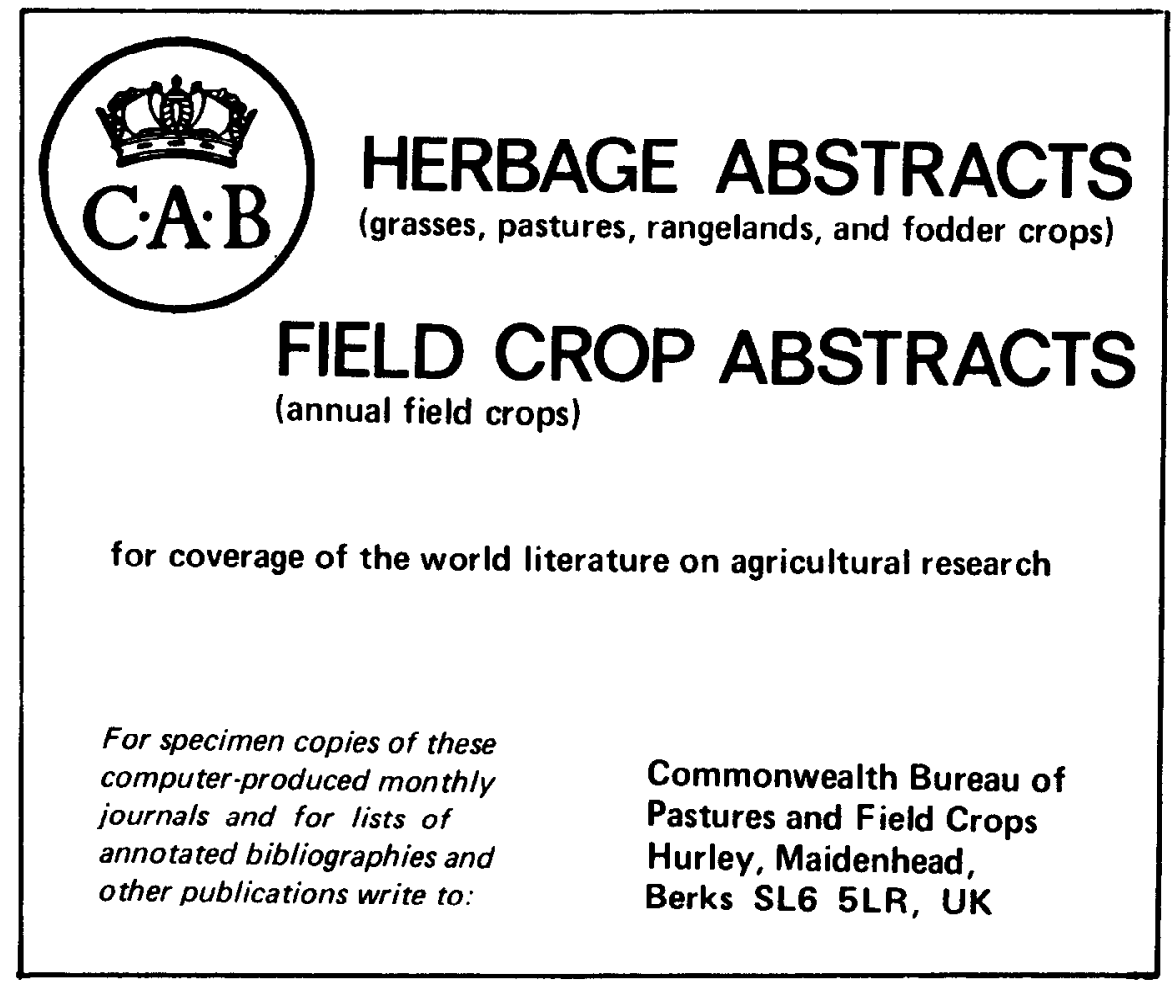

